낙동강수계 교통지역 비점오염원 유출특성분석 및 원단위 산정

\title{
Analysis of Nonpoint Source Pollution and Calculation of Load Per Unit Area in Transportation Area in Nakdong River Basin
}

\author{
권헌각* - 임태효** - 신동석*** - 이춘식**** \\ Kwon, Heongak ${ }^{*}, \mathrm{Im}$, Taehyo $^{* *}$, Shin, Dongsuk ${ }^{* * *}$, and Lee, Chun Sik ${ }^{* * * *}$
}

\begin{abstract}
In this study, the runoff characteristics were analyzed by using long-term monitoring results in the Nakdong River watershed traffic area, and the load per unit area of nonpoint source was estimated. Based on the estimates of the basic load per unit area and existing water TMDL, the reduction load for each nonpoint source pollution reduction facility was calculated and compared. As a result of long-term monitoring data analysis on the Nakdong River watershed traffic area, the average number of rainfall-free days was 6.7 days. The mean rainfall was $31.3 \mathrm{~mm}$ and the duration of rainfall was 9.1 hours. The points of investigation were the land cover which showed $100 \%$ impervious rate due to some landscaping according to the shape of the road, but showed a characteristic of spillage even at low rainfall. The EMCs for nonpoint pollutants by road type were classified by rainfall class after calculating EMCs for each rainfall event. In case of nonpoint source pollutant flow weighted average concentration, the variation of value according to rainfall history varies, and even in the same area, the amount of runoff and quality of water changes are significant. EMCs are classified according to rainfall class according to characteristics of nonpoint pollution source concentration. As a result of estimating the non-point pollution source unit for the secondary land cover standard traffic area, BOD was calculated to be 12.42 $\mathrm{kg} / \mathrm{km}^{2} / \mathrm{day}$. The BOD of $17.76 \mathrm{~kg} / \mathrm{km} / \mathrm{day}$, T-N of $13.69 \mathrm{~kg} / \mathrm{km}^{2} / \mathrm{day}$ and T-P of $0.631 \mathrm{~kg} / \mathrm{km}^{2} /$ day were applied somewhat higher than the standard values calculated in this study. The reduction load calculated on the basis of the sub-division basis is the base data for evaluating the load according to the development after pre-application in road development in the target watershed. It is difficult to estimate the exact load for the specific coating to be analyzed by applying the common unit value for the pitcher land cover (residential, industrial, commercial, traffic, etc. In this study, the load is estimated by applying the calculated unit load for the traffic area.
\end{abstract}

Key words : Nonpoint Source, Load Per Unit Area, Reduction Load

\section{요 지}

본 연구에서는 낙동강수계 교통지역에서의 장기모니터링 결과를 활용하여, 대상 피복에 대한 유출특성을 분석하고, 비점오염원 원단위를 산정하였다. 산정된 원단위 및 기존 수질오염총량지침에서 적용되고 있는 대분류 원단위를 활용하여 대상유역인 교통지역에 대한 비점오염원 저감시설별 삭감부하량을 산정하여 비교하였다. 낙동강수계 교통지역에 대한 장기모니터링 자료 분석 결과, 선행무강우일수는 평균 6.7일로 조사되었으며, 해당 지점의 강우량은 평균 $31.3 \mathrm{~mm}$, 강우지속시간은 9.1 시간으로 조사되었다. 조사대상 지점은 도로의 경우 형태에 따른 일부 조경에 의한 차이는 있으나 $100 \%$ 불투수율을 나타내는 토지피복으로 적은 강우량에도 유출을 나타내는 특성을 보였다. 도로 형태별 비점오염원에 대한 유량가중평균농도(EMCs)의 경우 각각의 강우사상에 대한 EMCs를 산정한 후 강우계급별 구분하여 제시하였다. 비점오염원 유량가중평균농도의 경우 강우사상에 따른 값의 변화가 다양하고, 동일한 지역에 동일한 강우사상이더라도 유출수의 양과 수질 변화가 큰 특성을 나타낸다. 이러한 비점오염원 농도 특성에 따라 EMCs를 강우계급별로 구분하고 제시하였다. 중분류 토지피복 기준 교통지역에 대해 비점오염원 원단위를 산정한 결과, BOD $12.42 \mathrm{~kg} / \mathrm{km} / \mathrm{day}, \mathrm{T}-\mathrm{N} 7.553 \mathrm{~kg} / \mathrm{km} / \mathrm{day}, \mathrm{T}-\mathrm{P} 0.391 \mathrm{~kg} / \mathrm{km} / \mathrm{day}$ 로 산정되었다. 기존 수질오염총량관리지 침 기준 토지계 비점원단위의 경우 BOD $17.76 \mathrm{~kg} / \mathrm{km}^{2} / \mathrm{day}, \mathrm{T}-\mathrm{N} 13.69 \mathrm{~kg} / \mathrm{km} / \mathrm{day}, \mathrm{T}-\mathrm{P} 0.631 \mathrm{~kg} / \mathrm{km} / \mathrm{day}$ 로 본 연구에서 산정된 원단위에 비해 다소 높게 적용되었다. 중분류 원단위 기준 산정된 삭감부하량은 대상 유역에서 도로개발 시 사전 적용 후 해당 개발에 따른 부하량을 평가 할 수 있는 근거 자료가 된다. 기존 대분류 토지계 비점원단위의 경우 불투수 토지피복(주거, 공업, 상업, 교통 등)에 대해 공통적인 원단위 값을 적용하여, 분석하고자 하는 특정 피복에 대한 정확한 부하량 산정은 어려운 실정이었다. 본 연구에서는 교통지역에 대해 산정된 원단위를 적용하여 부하를 산정하였으며, 이러한 원인으로 인해 원단위 감소에 따른 저감효율 감소 결과를 나타낸 것으로 사료된다. 핵심용어 : 비점오염원, 원단위, 삭감부하량

*정회원, 낙동강물환경연구소 전문위원(E-mai: hunkah@naver.com)

Member, Researcher, Nakdong River Environment Research Center

**정회원, 낙동강물환경연구소 연구관

Member, Researcher, Nakdong River Environment Research Center

***정회원, 낙동강물환경연구소 연구관

Member, Researcher, Nakdong River Environment Research Center

****교신저자, 정회원, 경남과학기술대학교 교수(Tel: +82-55-751-3347, Fax: +82-55-751-3484, E-mail: cslee@gntech.ac.kr)

Corresponding Author, Member, Professor, Department of Environmental Engineering, Kyeongnam National University of Science and Technology 


\section{1. 서 론}

물 순환은 강우에 의한 지표 유수의 흐름, 지표하부로의 침투와 대기 중으로의 증발 및 증산을 통해 이루어진다. 이러한 자연의 물순환 구조는 지하수, 기후조절 그리고 경관 및 친수성을 활용한 이용가치가 있는 반면, 강우패턴의 변화 와 더불어 밀도 높은 도시화로 인한 불투수면적의 증가로 각종 도시문제를 발생시키는 문제의 중심에 있기도 하다. 따라서 물 순환의 기본적인 원리에서 벗어난 불투수면적의 증가는 다른 도시문제를 일으키며 그 심각성은 매우 크다고 할 수 있다(Committee for the Youngsan River - Seomjin River Water Management System, 2015). 그 동안 산업폐수 및 생활하수 등 점오염원으로부터의 배출부하량은 배출허 용기준의 강화에 따른 고도처리 등, 기술개발 및 확대적용의 결과로서 점차 축소되어 왔으나, 비점오염원으로부터의 배 출부하량은 지역개발에 따른 불투수성 토지이용의 증가에 비례하여 꾸준히 증가되어 왔다(Kwon, 1998). 토지이용형 태의 급격한 변화(도시화, 공업화)에 따라 토지이용이 고밀 도로 이루어지고 있기 때문에 전체 오염유출량에 대한 비점 오염 유출량이 점하는 비율이 증가하는 경향에 있으며, 비점 오염원의 경우 강우에 의해 유출되어, 직접적으로 하천에 유입되고 있다. 따라서 수역의 수질을 적절히 관리하기 위해 서는 유역 내에 분포하는 비점오염 발생량의 공간적 시간적 분포를 우선적으로 파악함과 아울러 수역으로 유출되는 오염발생량을 양적 - 질적인 측면에서 규명하는 것이 대단 히 중요하다(Kwon, 2011). 또한 비점오염원은 강우 시 주로 토지계 오염원에서 배출되는 특성을 가지고 있어 수계오염 총량제 지침에서 제시하고 있는 토지계 원단위를 통해서 비점오염원 발생부하량을 산정하기도 하나 원단위 산정 시 주거지역 및 시가지 지역에서 과대 산정되는 경향을 가지고 있어 정확한 비점오염원 부하량을 산정하는데 그 한계를 가진다. 비점오염원 부하량을 산정하기 위해서 지금 까지 다양한 방법들이 제시되어 왔고, 환경부에서는 기존의 조사 결과를 종합하여 토지이용에 따른 오염물질 배출부하 량을 산정하는 방법으로서 원단위법을 규정한 바 있다(Shin, 2007). 이와 같이 유역별로 다양하게 발생되고 있는 비점오 염원을 효과적으로 관리하기 위해서는 오염부하량을 정량 적으로 산정하고 이동 경로를 파악하는 것이 필수적이다 (Choi et al., 1997). 비점오염원에 대한 관리 초기에는 오염부 하량을 감소시켜 수질을 보호하고자 하였으나, 최근 비점오 염원 저감 이외에 유출량 저감, 지하수 충진 등과 같은 효과를 볼 수 있는 비점오염 저감시설이 주목을 받고 있다(Lee, 2016; Valinski and Chandler, 2015). 이와 같은 시설들은 Lid (Low Impact development) 시설로 구분되며, 식생수로, 식생여과대, 인공습지 및 침투저류지 등이 있다(Hong and $\mathrm{Kim}, 2016$ ). 이와 같은 저감시설을 활용한 비점오염원 관리 는 안정적인 수질 확보를 위해 큰 역할을 할 것으로 전망하고
있다(Moore and Hunt, 2012). 본 연구에서는 낙동강수계 교통지역에서의 장기모니터링 결과를 활용하여, 대상 피복 에 대한 유출특성을 분석하고, 비점오염원 원단위를 산정하 였다. 산정된 원단위 및 기존 수질오염총량지침에서 적용되 고 있는 대분류 원단위를 활용하여 대상유역인 교통지역에 대한 비점오염원 저감시설별 삭감부하량을 산정하여 비교하 였다. 산정된 삭감부하량은 해당 피복과 같이 교통지역(도로) 개발 행위 시 개발 전·후의 비점부하량 산정 시 기준 자료로 활용될 수 있다.

\section{2. 연구방법}

\section{1 조사대상 유역}

모니터링 조사대상 지점은 창원시와 진주시에 위치한 교통지역으로 조사대상 도로 형태는 고속도로, 국도 및 간선도로로 구분하였다(Fig. 1). 고속도로의 경우 중부내륙 고속도로로 대전-통영간 상행선으로써 왕복 4차선으로 되 어있다. 이 중 상행선 편도 2차선을 대상지점으로 선정하여 중앙분리대 및 노선 주변 갓길을 포함하여 강우 시 우수관거 로 유입되는 유출수를 대상으로 모니터링을 수행하였다. 국도의 경우 창원시 가포동에 위치한 가포터널 앞의 노면 유출수를 대상으로 하였다. 간선도로의 경우, 창원천 주변 도심지 내 위치하고 있으며 편도 3차선으로 되어 있는 지점 이다. 기존 침전물들의 영향을 배제하기 위하여 우수관거 내 침적된 오염물을 정비 후 모니터링을 실시하였다. 조사대 상 지점이 진주시와 창원시로 시도구간이 나뉘어 있어 강우 자료 분석을 위해 인간 기상관측소인 진주 및 창원 관측소의 최근 10 년간 측정된 시간기준 자료를 활용하였다.

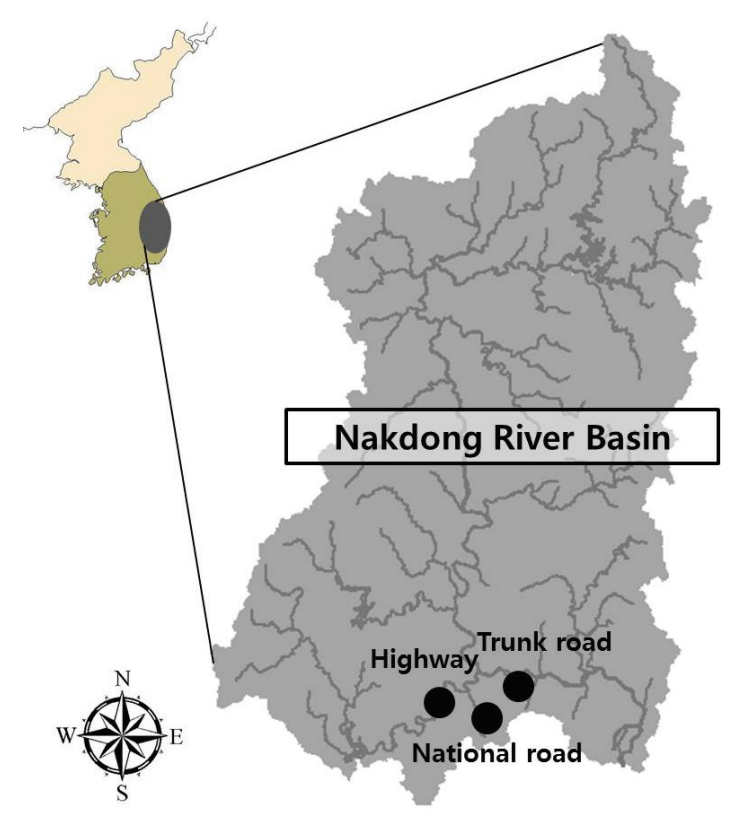

Fig. 1. Survey Sites in this Study 


\section{2 비점오염원 강우유출수 모니터링 및 원단위 산정}

강우유출수에 대한 특성을 조사하기 위하여 2007년 예비 조사를 시작으로 2013년까지 낙동강수계 내 교통지역에 대한 강우 시 비점오염원 유출수에 대한 모니터링을 수행 하였다. 모니터링 시점은 기상청의 일기예보를 바탕으로 조사 대상 지점에 강우강도계 및 유량계를 설치하여 조사 대상지점에서 일어나는 강우 형태에 따른 유출수의 변화를 모니터링 하였다. 실측에 사용된 강우강도계는 Tipping Bucket Mechanism 방식의 호주 Environdata Environmental Monitoring \& Management 사의 RG-20으로 $1 \mathrm{~min}$ 단위의 강우량 측정이 가능하고, 유량계의 경우 비만관 전자식 유량 계로 미국 MARSH McBIRNEY 사의 Flo-Tote3로 1분 단위의 유량측정이 가능하다. 조사대상지점에 대한 유량계 의 설치는 최종 유출구에 설치하여 외부로부터 강우유출수 의 유입이 없는 상황에서 유출량을 조사 하였다. 시료의 채취 및 분석은 NIER (2012)에서 개정된 '강우 유출수 조사 방법'에 준하여 이루어 졌고, 강우량 및 유출량의 경우 현장 조사를 원칙으로 하였고, 불가할 시 가장 근접한 기상청 자료를 활용하였다.

비점오염원은 우수유출과 밀접한 관련을 가지고 있으며 강우 유출은 토지이용, 경사도, 식생, 강우강도 등에 따라 차이가 심하다. 유출계수(C)는 유역 상에 일정기간 동안 내리는 강수량으로 인해 유출되어, 그 유역의 출구를 통과하 는 유출량의 총강우량에 대한 비율을 뜻하므로 유역의 지형 및 지질 등에 의해 결정된다. 유출계수는 단기로는 홍수 시 유출계수에서 장기로는 월별, 연별 유출계수가 있을 수 있으며 홍수 시 유출계수가 장기유출계수보다 크다. 유출계 수 값은 오염물질의 유출량과 밀접한 관계를 가지고 있으며 다음의 Eq. 1과 같이 나타낼 수 있다(MOE, 1995). 유출고는 강우 시 총수량을 유역면적으로 나눈 값으로 표시된다.

$$
\begin{gathered}
C=V_{d} / \sum_{m=1}^{M} R_{m} \\
V_{j}=\sum_{i=1}^{N} Q_{i} \cdot \Delta t
\end{gathered}
$$

여기서, $V_{j}=j$ 지점의 강우 시 총수량 $\left(\mathrm{m}^{i}\right), Q_{j i}=j$ 지점의 $i$ 번째 유량 $\left(\mathrm{m}^{3} / \mathrm{sec}\right), \sum_{m=1}^{M} R_{m}=$ 총강우량(total rainfall, $\left.\mathrm{mm}\right)$, 유출고(depth of runoff) $=V_{d}=\mathrm{V} /$ 유역면적 이다. 또한 비점오 염 부하는 여러 가지 요인에 따라서 배출되는 부하가 다르기 때문에 이에 대한 적절한 평균농도를 도입하여 특정 강수 시기의 비점오염원의 평균 오염물질 농도로 나타낼 필요가 있다. 평균농도를 산정하는 가장 간단한 방법인 산술 평균농 도는 시간간격이 일정할 경우에는 타당한 평균농도로서
제시될 수 있지만, 비점오염원 유출은 실시간으로 변화되는 유출량과 농도의 변화가 있어, 샘플채취가 일정간격으로 이루어지지 않아 산술평균에 의한 평균농도로서는 대표성 을 갖지 못하는 단점이 있다.

강우계급 $\mathrm{y}$ 의 평균 유량가중평균농도, $\mathrm{EMC}_{\mathrm{y}}(\mathrm{mg} / \mathrm{L})$ 는 해당 강우계급에 속하는 강우사상들에 대해 산정된 $\mathrm{EMC}_{\mathrm{x}}$ 로 부터 다음의 식으로 산정한다.

$$
E M C_{y}=\frac{\sum_{n=1}^{N}\left(E M C_{x n}\right)}{N}
$$

여기서, $\mathrm{EMC}_{\mathrm{xn}}$ 는 강우계급 $\mathrm{y}$ 에 해당하는 전체 $\mathrm{N}$ 개의 강우사상 중 $\mathrm{n}$ 번째 강우사상의 $\mathrm{EMC}(\mathrm{mg} / \mathrm{L})$ 이다.

원단위를 이용한 비점오염부하량 산정은 적용이 간편하 기 때문에 많은 국가에서 사용하고 있다. 그러나 비점오염원 은 기후, 지형, 일시, 수문조건에 따라 배출양상이 다양하므 로 정확한 원단위의 산정을 위해서는 장기간(최소한 5년 이상)에 걸친 연속 측정된 실측자료를 바탕으로 해야 한다. 우리나라에서는 1980년대 초반부터 비점오염원단위를 산 정하기 시작하였으나 아직까지는 자료의 축적이 부족하여 토지이용별 정확한 원단위 파악과 토지이용과 연계한 비점 오염원 유출량 산정에는 한계가 있다. 그리고 대부분의 원단 위가 단일강우 또는 2-3회의 실측자료를 이용하였으므로 각 토지이용에서의 비점오염유출특성을 충분히 반영하지 못하였고, 토지이용구분도 각 토지이용별 세부구분을 하지 못하고 농지, 산지, 도시 등 3-5개의 토지이용구분을 통해 유역의 비점부하량을 산정하여 세부 토지이용별 상세한 원단위 산정은 이루어지지 못했다.

원단위산정기준은 발생량기준, 유출량기준, 유달량 기준 의 세가지로 구분할 수 있다. 발생량기준은 단위토지이용에 서 단위시간에 발생한량을 말하며, 유출량기준은 발생해서 비점오염원으로 수역으로 유출되는 양을 기준으로 한 경우 를 말하며, 유달부하량 기준은 특정지점까지 비점오염원이 배출, 즉 유달되는 양을 기준으로 본다. 본 연구에서는 강우 시 비점오염물질이 유출되는 양을 실측하여 산정하였기 때문에 비점오염원 유출부하원단위에 해당한다.

비점오염원단위를 간단히 정의하면 단위시간당 단위토 지면적에서 배출되는 오염물질량을 말하며, 단위는 일반적 으로 비점오염부하량 $\left(\mathrm{kg}\right.$ 또는 ton)/면적(ha 또는 $\left.\mathrm{km}^{2}\right) /$ 시간 (year 또는 day)으로 나타낸다. 비점오염원의 토지이용별 원단위에 대해서는 많은 문제점도 제기되고 있지만 사용의 간편성과 기존자료의 적용편이성으로 인해 많이 이용되고 있으며 비점오염원 모델에서도 토지이용, 토양특성 및 수리 수문학적 사항들과 함께 토지이용별로 원단위 관계식들이 많이 사용되고 있다. 현재 사용되고 있는 원단위산정법으로 는 경험식 등을 이용한 계산법과 유역에서 유량과 오염부하 
량을 실측해서 산정하는 실측법이 있다. 실측법은 조사방법 에 따라 크게 3 가지로 구분할 수 있다. 첫 번째는 지표면에서 오염물질 총량을 실측한 후 축적율 및 분해율을 적용하는 방법으로 주로 도시지역에서 비점오염원 원단위를 산정하 는데 이용된다. 두 번째 방법은 강우 시 특정지역을 통과하 는 하천상류와 하류의 수질을 비교하여 수질의 차이를 환산하여 당해 유역에서의 비점오염물질 배출원단위를 산정하는 방법이다. 세 번째 방법은 토지이용별 강우 시 배출물질을 직접 채취하여 농도를 측정하는 방법으로서 측정횟수가 충분하면 원단위산정에서 가장 신빙성이 있는 방법이다. 이 방법은 토지이용별 강우 시 유출수량과 오염 부하량을 실측하여 단일강우사상, 월간, 계절간 또는 연간 오염물질의 원단위 계산뿐 아니라 실측한 유량, 강우량, 오염물질 유출량 등을 이용해 각종 회귀식을 이용해 상호관 계를 규명하는데 이용하기도 한다. 주요국가의 원단위 산 정방법은 각국의 기초자료 축적 상태에 따라 결정된다. 기본 자료가 충실한 미국의 경우, 원단위를 작성코자하는 오염물질에 대해 수년의 연속측정 수질자료와 수량자료를 이용해 원단위를 산정하고 있다. 즉 시료자동채취기와 유 량자동측정기를 이용해 유량자료를 자동으로 원격송신하 고 수질 중 온도와 용존산소는 현지에서 직접 실측하여 자료를 전송하고 $\mathrm{pH}$, 탁도, 알카리도 등은 시료 채취 후 즉시 실험을 시행한다. 그리고 $\mathrm{SS}$, 각종 질소 $\left(\mathrm{NH}_{3}-\mathrm{N}\right.$, 용존 유기질소, 퇴적물 부착질소 등), 인(용존인, 퇴적물부착인 등)은 시료채취 후 냉동보관해서 실험실로 운반하여 분석 한 농도를 유량과 결합시켜 단일 강우사상별, 연별 원단위 를 산정하여 계산식은 다음과 같다.

$$
\text { 원단위 }(\mathrm{kg} / \mathrm{ha} / \text { year })=\sum \mathrm{c}_{\mathrm{i}} \mathrm{q}_{\mathrm{i}} / \mathrm{A}
$$

여기에서 $\mathrm{c}_{\mathrm{i}}$ : i번째 농도, $\mathrm{q}_{\mathrm{i}}$ : i번째 유출량, $\mathrm{A}$ : 유역면적

장기간의 연속자료가 없는 경우, 수회의 강우유출-오염측 정자료를 이용해 이를 연간의 강우량이나 유출량과 연결시켜 연간 비점오염원단위를 산정하고 있으며 식은 다음과 같다.

$$
\text { 원단위 }(\mathrm{kg} / \mathrm{ha} / \mathrm{year})=\mathrm{k} \sum \mathrm{c}_{\mathrm{i}} \mathrm{q}_{\mathrm{i}} \mathrm{t}_{\mathrm{i}} * 365 / \sum \mathrm{t}
$$

여기에서 $\mathrm{c}_{\mathrm{i}}$ : $\mathrm{i}$ 번째 농도, $\mathrm{q}_{\mathrm{i}}$ : $\mathrm{i}$ 번째 유출량, $\mathrm{t}_{\mathrm{i}}$ : 시료와 관련된 시간간격 [(전회시료채취시기 - 당회시료채취시 기) $/ 2+($ 당회시료채취시기-다음시료채취시기/2)], $\mathrm{k}$ : 변 환계수, $365 / \sum \mathrm{t}$ : 연간단위 환산계수이다. 이와 같은 방식 은 일년 동안 연속해서 비점오염원을 실측조사 할 수 없기 때문에 시료를 채취한 기간에 대해 계산한 값을 연간 으로 환산하여 사용하는 것이다. 원단위를 연간으로 환산 하는 방법은 강우회수적용법, 우량가중농도법, 유출량가중 농도법 등이 있다(Committee for the Nakdong River water management system, 2007).

Table 1. Calculation Methods of NPS Basic Unit

\begin{tabular}{l|l}
\hline \multicolumn{1}{c|}{ Methods } & \multicolumn{1}{c}{$\begin{array}{c}\text { Calculation } \\
\text { expression }\end{array}$} \\
\hline - Application method of precipitation & $\mathrm{L}=\mathrm{NI}_{\mathrm{a}}$ \\
frequency & $\mathrm{L}=\mathrm{I}_{\mathrm{a}}\left(\mathrm{P}_{\mathrm{a}} / \mathrm{p}_{\mathrm{a}}\right)$ \\
- Method of valid precipitation ratio & $\mathrm{L}=\mathrm{I}_{\mathrm{m}}\left(\mathrm{Q}_{\mathrm{m}} / \mathrm{q}_{\mathrm{m}}\right)$ \\
- Method of discharge ratio & $\mathrm{L}=\mathrm{N}\left[\mathrm{I}_{\mathrm{a}}\left(\mathrm{Q}_{\mathrm{a}} / \mathrm{q}_{\mathrm{a}}\right)\right]$ \\
- Method of discharge-weighting & \\
\hline
\end{tabular}

여기서, L: 년간 부하량, $\mathrm{N}$ : 년간 유출이 일어난 횟수, $\mathrm{I}_{\mathrm{a}}$ : 출수당 평균부하량, $\mathrm{P}_{\mathrm{a}}$ : 년간 평균유효우량, $\mathrm{p}_{\mathrm{a}}$ : 표본에서 의 일출수당 평균유효우량, $\mathrm{Q}_{\mathrm{m}}$ : 년간 유출량, $\mathrm{q}_{\mathrm{m}}$ : 실측기간에 서의 유출량, $\mathrm{I}_{\mathrm{m}}$ : 실측기간에서의 평균유량가중농도, $\mathrm{Q}_{\mathrm{a}}$ : 모 집단에서 일출수당 평균유출량, $\mathrm{q}_{\mathrm{a}}$ 표본에서의 일출수당 평균유출량 이다.

\section{3 비점오염저감시설의 규모 및 용량결정}

비점오염저감시설의 설치 및 관리운영 매뉴얼(MOE, 2016)에 따르면, 저감시설이 지나치게 과대해지지 않도록 유역의 유량 및 오염부하 등 다양한 기초조사를 통해 최적의 시설 규모를 산정하는 것이 바람직하다. 비점오염저감시설 의 규모 결정 예는 다음과 같다. 대상유역의 적정 강우사상에 대한 수문곡선(Hydrograph)과 오염곡선(Pollutograph)을 이 용하여 수질이 건기상태로 회복되는 시점, 즉 강우초기에 평시 수계의 수질보다 악화되었다가 다시 강우유출수 수질 이 건기 유출수 수질로 회복하는 시점까지의 유량으로 규모 를 설정하는 것이 좋다. 비점오염저감시설의 규모 및 용량을 결정할 때에는 상기 항에 의한 방법과 아울러 해당지역의 강우빈도 및 유출수량, 오염도 분석에 따른 비용효과적인 삭감목표량 및 기타 정책적인 삭감 목표량, 관련 규정 등에 따라 설계 강우량을 설정할 수 있으나, 그 결과가 배수구역의 누적유출고로 환산하여 최소 $5 \mathrm{~mm}$ 이상의 강우량을 처리할 수 있는 규모에 합치하여야 한다. 기준이 되는 규모의 결정은 다음의 방법에 따른다.

$$
\mathrm{WQv}=\mathrm{P} 1 \times \mathrm{A} \times 10-3
$$

이에 저류시설, 인공습지 등 강우유출수를 초기에 저류하 여 처리하는 시설은 수질처리용량 $\left(\mathrm{WQv}, \mathrm{m}^{3}\right)$ 을 활용하여 시설의 용량 및 규모를 결정할 수 있으나 강우유출수를 연속 하여 처리하는 시설인 장치형 시설과 자연형 시설 중 식생여 과대 및 식생수로 등은 수질처리유량 $\left(\mathrm{WQF}, \mathrm{m}^{3} / \mathrm{h}\right)$ 으로 설계 가 이루어지므로 시설별 특성에 부합하는 용량설계기준을 적용하여 설계하는 것이 좋다. 수질오염총량관리를 위한 비점 
오염원 최적관리지침(NIER, 2012)에서 수질처리용량(WQv) 을 산정하는 방법은 다음과 같은 식을 제시하고 있다.

$$
\mathrm{WQv}=10^{-3} \times \mathrm{P} \times \mathrm{A} \times \mathrm{Rv}
$$

여기서, $\mathrm{WQv}=$ 수질처리용량 $\left(\mathrm{m}^{3}\right), \mathrm{A}=$ 유역면적 $\left(\mathrm{m}^{2}\right)$, $\mathrm{P}=$ 설계강우량 $(\mathrm{mm}), \mathrm{RV}=$ 체적유출계수 $(=0.05+0.009 \times \mathrm{I}$, $\mathrm{I}=$ 불투수율 $(\%))$ 이다.

수질오염총량관리를 위한 비점오염원 최적관리지침에서 의 수질처리용량 산정 방법이 매뉴얼에서 제시하는 수질처 리용량 산정식과는 달라 비점오염저감시설을 설계하고자 할 때 다소 혼란의 소지가 있어 두 식과의 관계와 차이를 기술하고자 한다.

※「수질 및 수생태계 보전에 관한 법률」에서는 누적유출 고 $5 \mathrm{~mm}$ 이상을 처리할 수 있도록 규정하고 있어 동법에 따라 시설을 설치하고자 할 경우에는 법적인 규정을 준수하여야 하므로 본 매뉴얼에서 제시하는 산정식을 적용하는 것이 타당하다. 반면에 수질오염총 량관리를 위한 비점오염저감시설을 설치할 경우에는 설계강우량이 증가할수록 강우처리비 및 삭감대상부 하비가 증가하므로 보다 많은 삭감량을 계획할 경우에 는 설계강우량( $\mathrm{P})$ 을 높게 설정하므로 이를 고려한 산정 식을 제시하고 있다. 따라서 본 매뉴얼에서 제시하는 식과「수질오염총량관리를 위한 비점오염원 최적관리 지침」에서 제시하는 식은 다음의 기준을 만족할 경우 모두 사용할 수 있다.
여기서, $\mathrm{P}$ : 설계강우량 $(\mathrm{mm}), \mathrm{P} 1$ : 설계강우량으로부터 환 산된 누적유출고 $(\mathrm{mm})$ 이다. 비점오염저감시설은 $\mathrm{WQV}$ 를 처리할 수 있는 규모로 설계한다.

비점오염원 삭감부하량 산정은 수질오염총량과리를 위 한 비점오염원 최적관리지침(NIER, 2014)을 활용하였다. 비점오염삭감부하량은 개발 지역의 비점오염관리계획을 적용하기 전과 적용한 후에 발생하는 부하량의 차이이다 (Committee for the Youngsan River - Seomjin River Water Management System, 2015). 개발부지 내에 소규모 비점오염 저감시설들을 분산 적용하는 것을 권장하고 있으며, 이로 인한 편의를 위하여 각 소규모 시설들의 저류용량을 이용하 여 개략 산정하도록 하고 있다. 비점오염 삭감부하량은 수질 처리용량의 설계강우량을 기준으로 산정한 삭감대상부하비 와 해당 비점오염저감시설의 저감효율을 이용하여 산정 한다.

$$
\begin{aligned}
& \text { 강우처리비 }=0.2716 \times \ln (\mathrm{P})-0.2425 \\
& \begin{array}{l}
\text { 삭감대상부하비 }=\exp \left[-0.0184 \times\{\ln (\text { 강우처리비 })\}^{2}\right. \\
\quad+0.6922 \times \ln (\text { 강우처리비 })]
\end{array}
\end{aligned}
$$

삭감부하량 $(\Delta \mathrm{L})=\mathrm{A} \times \mathrm{UL} \times$ 삭감대상부하비

$$
\times \mathrm{E} / 100
$$

여기서, $\Delta \mathrm{L}$ 은 삭감부하량 $(\mathrm{kg} / \mathrm{day}), \mathrm{A}=$ 집수유역면적 $\left(\mathrm{km}^{2}\right), \mathrm{UL}=$ 집수유역의 원단위 $\left(\mathrm{kg} / \mathrm{km}^{2} / \mathrm{day}\right), \mathrm{E}=$ 저감시설의 저감효율 $(\%)$ 이다.

$\mathrm{WQv}=10-3 \times \mathrm{P} \times \mathrm{A} \times \mathrm{Rv} \geq 10-3 \times \mathrm{P} 1 \times \mathrm{A}$

Table 2. In this Study, Reduction Efficiency by Nonpoint Source Pollution Reduction Facility (NIER, 2014)

(Unit: \%)

\begin{tabular}{l|c|c|c}
\hline \multicolumn{1}{c|}{ Nonpoint pollution reduction facility } & BOD & T-N & T-P \\
\hline Infiltration ditch & 77 & 62 & 73 \\
\hline Trees filtration box & 54 & 49 & 65 \\
\hline Infiltration gutter & 53 & 72 & 46 \\
\hline
\end{tabular}

Table 3. Number of Investigation by Precipitation Class in Traffic Area

\begin{tabular}{c|c|c|c|c|c|c}
\hline \multirow{2}{*}{ Class of rainfall } & \multicolumn{2}{|c|}{ Highway } & \multicolumn{2}{c|}{ National road } & \multicolumn{3}{c}{ Trunk road } \\
\cline { 2 - 7 } & $\begin{array}{c}\text { Number of } \\
\text { investigation } \\
(\%)\end{array}$ & $\begin{array}{c}\text { Cumulative } \\
\text { rainfall } \\
(\mathrm{mm})\end{array}$ & $\begin{array}{c}\text { Number of } \\
\text { investigation } \\
(\%)\end{array}$ & $\begin{array}{c}\text { Cumulative } \\
\text { rainfall } \\
(\mathrm{mm})\end{array}$ & $\begin{array}{c}\text { Number of } \\
\text { investigation } \\
(\%)\end{array}$ & $\begin{array}{c}\text { Cumulative } \\
\text { rainfall } \\
(\mathrm{mm})\end{array}$ \\
\hline $0 \sim 10 \mathrm{~mm}$ & $7(20)$ & 48.9 & $8(25)$ & 59.8 & $9(25)$ & 59.8 \\
\hline $10 \sim 30 \mathrm{~mm}$ & $17(48.6)$ & 328.8 & $11(34.3)$ & 283.1 & $15(41.6)$ & 283.1 \\
\hline $30 \sim 50 \mathrm{~mm}$ & $5(14.3)$ & 191.1 & $7(21.9)$ & 235.1 & $6(16.7)$ & 235.1 \\
\hline$>50 \mathrm{~mm}$ & $6(17.1))$ & 417.2 & $6(18.8)$ & 575.7 & $6(16.7)$ & 575.7 \\
\hline Total & $29(100)$ & 568.8 & $26(100)$ & 1153.7 & $36(100)$ & 1153.7 \\
\hline
\end{tabular}




\section{3. 연구결과}

\section{1 교통지역 비점오염원 모니터링 결과}

낙동강수계 교통지역(도로)에 대해 2007년부터 2013년까 지 수행된 모니터링 결과를 분석하였다. 도로 형태별로 구분 하여 강우유출수에 대한 모니터링을 수행하였으며, 해당 모니터링 횟수를 정리하여 Table 3 에 나타내었다.

조사대상 교통지역은 다양한 세부토지피복을 내포하고 있으나, 본 연구에서는 국내 가장 많이 분포된 고속도로, 국도 및 간선도로로 구분하여 모니터링을 수행하였으며, 강우 시작 후 유출이 종료되는 시점을 기준으로 하여 전수조 사를 실시하였다. 도로형태별 강우계급에 따른 조사 횟수는 $10 \sim 30 \mathrm{~mm}$ 강우계급의 조사 횟수(고속도로 $48 \%$, 국도 $34 \%$, 간선도로 $42 \%$ )가 가장 많았다. 누적강우량은 고속도로의 경우 $50 \mathrm{~mm}$ 이상의 강우계급이 $417.2 \mathrm{~mm}$ 로 가장 높게 조사되 었고, 국도 및 간선도로의 경우는 $575.7 \mathrm{~mm}$ 동일하게 조사되 었다. 국도 및 간선도로의 경우 조사지점이 유사하여 동일한 강우사상이 적용되었다.

강우 유출 및 유출수 관련 변수들을 분석하여 Table 4 및 Fig. 2에 나타내었다. 분석 대상 강우사상은 전수조사가 수행된 전 강우사상을 모두 포함하였으며, 항목은 선행무강 우일수, 총강우량, 강우지속시간, 첨두수질농도, 첨두수질
농도 도달시간, 첨두수질농도 도달 누적 강수량, 첨두유량, 첨두유량 도달시간, 첨두유량 도달 누적 강수량으로 선정하 였다. 불투수율이 높은 단일 토지피복의 경우, 초기유출수가 고농도로 유출됨으로 인한 영향이 하천수질에 많은 영향을 미치고 있어, 초기 강우 유출수에 대한 관리가 대상피복에 대한 비점오염원 관리 비중 중 가장 높게 차지하고 있다. Shin et al. (2004), 연구 논문에서는 도시지역의 경우 불투수 율이 높아 강우유출수의 양과 오염물질 양이 강우초기에 급속히 증가하는 초기유출현상이 두드러지고 있음을 도출 한 바 있다.

분석결과를 살펴보면, 선행무강우일수는 평균 6.7 일로 조사되었으며, 해당 지점의 강우량은 평균 $31.3 \mathrm{~mm}$, 강우지속 시간은 9.1시간으로 조사되었다. 조사대상 지점은 도로의 경우 형태에 따른 일부 조경에 의한 차이는 있으나 $100 \%$ 불투수율을 나타내는 토지피복으로 적은 강우량에도 유출 을 나타내는 특성을 보였다. 수질항목별 첨두수질농도를 분석한 결과, $\mathrm{BOD}$ 항목의 경우 간선도로의 농도가 44.0 $\mathrm{mg} / \mathrm{L}$ 로 가장 높게 조사되었으며, 국도 $(20.9 \mathrm{mg} / \mathrm{L})>$ 고속도로 $(14.9 \mathrm{mg} / \mathrm{L})$ 로 농도차이를 나타내었다. SS 항목의 경우도 $\mathrm{BOD}$ 와 유사한 경향을 나타내어 간선도로 $(194.5 \mathrm{mg} / \mathrm{L})>$ 국도 $(64.9 \mathrm{mg} / \mathrm{L})>$ 고속도로 $(47.9 \mathrm{mg} / \mathrm{L})$ 순으로 농도차이를 나타내었다.

Table 4. Analysis of Precipitation Runoff Characteristics in Traffic Area

\begin{tabular}{|c|c|c|c|c|c|}
\hline \multicolumn{2}{|l|}{ Road type } & Highway & National road & Trunk road & Ave. \\
\hline \multicolumn{2}{|l|}{ The number of dry day (day) } & 7 & 6 & 7 & 6.7 \\
\hline \multicolumn{2}{|l|}{ Total precipitation $(\mathrm{mm})$} & 29.0 & 30.7 & 34.3 & 31.3 \\
\hline \multicolumn{2}{|l|}{ Duration of precipitation (hr) } & 8.3 & 8.5 & 10.5 & 9.1 \\
\hline \multirow{5}{*}{ Peak water quality concentration $(\mathrm{mg} / \mathrm{L})$} & BOD & 14.9 & 20.9 & 44.0 & 26.6 \\
\hline & COD & 32.0 & 36.9 & 323.9 & 130.9 \\
\hline & SS & 47.9 & 64.9 & 194.5 & 102.4 \\
\hline & $\mathrm{T}-\mathrm{N}$ & 4.842 & 7.143 & 13.687 & 8.557 \\
\hline & $\mathrm{T}-\mathrm{P}$ & 0.440 & 0.286 & 1.380 & 0.702 \\
\hline \multirow{5}{*}{ Time to peak water quality concentration (hr) } & BOD & 2.04 & 0.98 & 0.82 & 1.28 \\
\hline & COD & 1.78 & 0.86 & 0.97 & 1.20 \\
\hline & SS & 1.81 & 1.36 & 1.42 & 1.53 \\
\hline & $\mathrm{T}-\mathrm{N}$ & 1.94 & 1.12 & 0.84 & 1.30 \\
\hline & $\mathrm{T}-\mathrm{P}$ & 1.93 & 1.24 & 1.08 & 1.42 \\
\hline \multirow{5}{*}{$\begin{array}{l}\text { Cumulative precipitation to peak water quality } \\
\text { concentration }(\mathrm{mm})\end{array}$} & BOD & 6.3 & 2.5 & 1.3 & 3.4 \\
\hline & COD & 4.4 & 2.2 & 1.7 & 2.8 \\
\hline & SS & 4.9 & 4.0 & 4.0 & 4.3 \\
\hline & $\mathrm{T}-\mathrm{N}$ & 5.1 & 3.7 & 1.0 & 3.3 \\
\hline & $\mathrm{T}-\mathrm{P}$ & 5.4 & 3.0 & 1.4 & 3.3 \\
\hline \multicolumn{2}{|l|}{ Peak flow $\left(\mathrm{m}^{3} / \mathrm{sec}\right)$} & 0.23 & 1.06 & 1.03 & 0.8 \\
\hline \multicolumn{2}{|l|}{ Peak flow reaching time (hr) } & 5.73 & 5.60 & 6.11 & 5.8 \\
\hline \multicolumn{2}{|l|}{ Cumulative precipitation to peak flow (mm) } & 21.7 & 21.9 & 21.1 & 21.6 \\
\hline
\end{tabular}




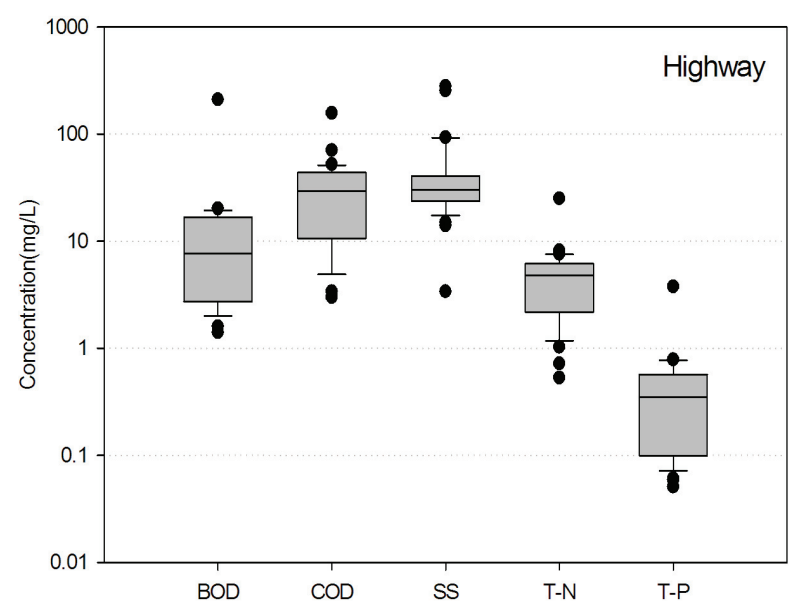

(a) peak water quality concentration

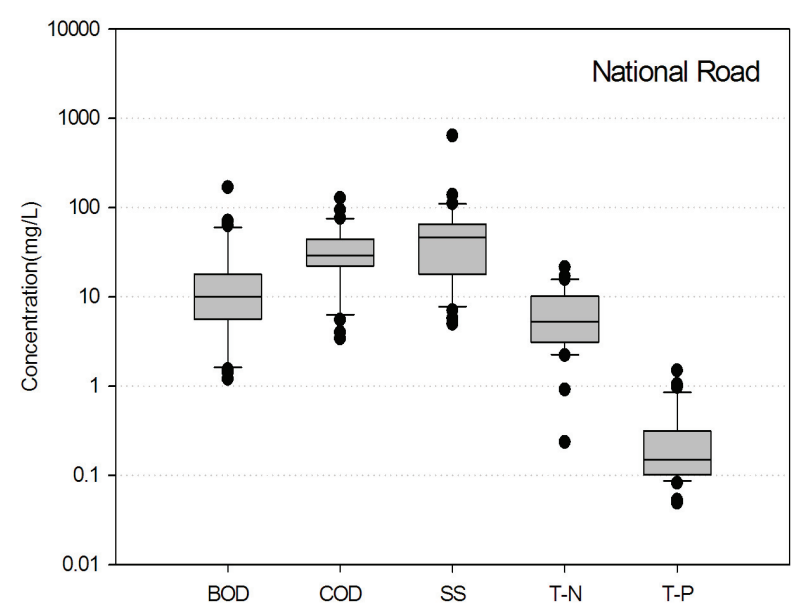

(c) peak water quality concentration

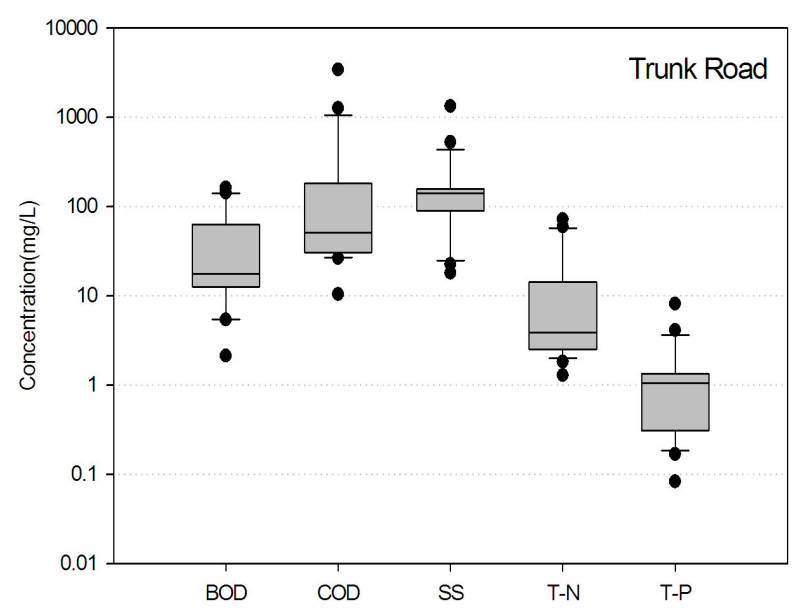

(e) peak water quality concentration

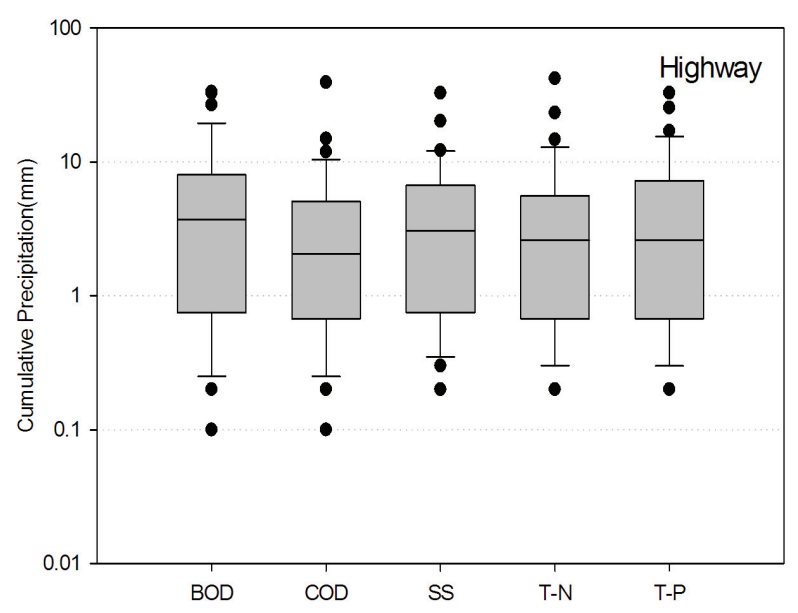

(b) cumulative precipitation

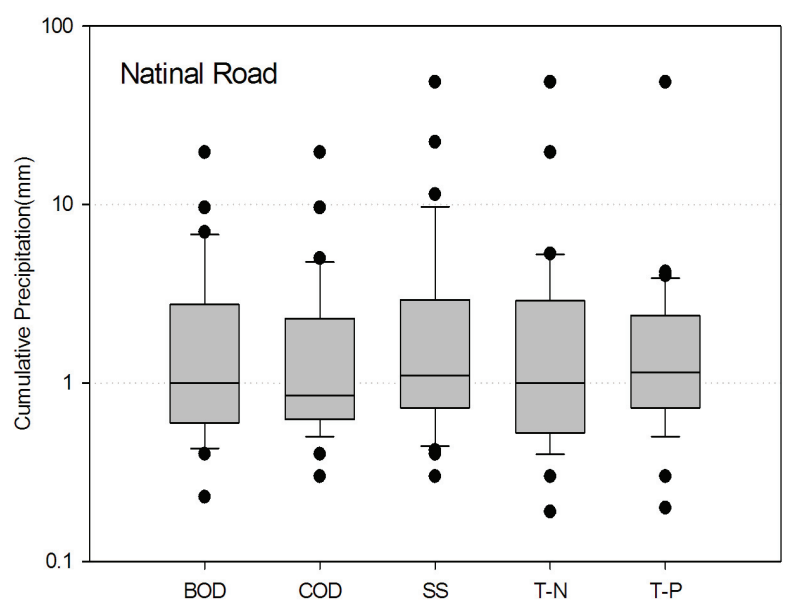

(d) cumulative precipitation

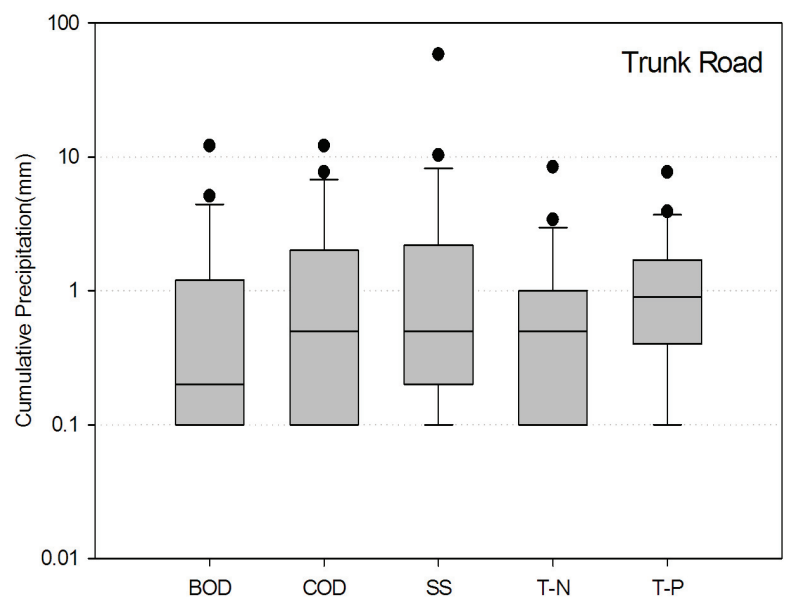

(f) cumulative precipitation

Fig. 2. Runoff Characteristics of Precipitation Runoff According to Road Type

대표적인 영양염류 물질인 T-N 항목은 간선도로(13.687 $\mathrm{mg} / \mathrm{L})>$ 국도 $(7.143 \mathrm{mg} / \mathrm{L})>$ 고속도로 $(4.842 \mathrm{mg} / \mathrm{L})$ 순으로 농도차이를 나타내었으나, T-P 항목의 경우 간선도로(1.380 $\mathrm{mg} / \mathrm{L})>$ 고속도로 $(0.440 \mathrm{mg} / \mathrm{L})>$ 국도 $(0.286 \mathrm{mg} / \mathrm{L})$ 다른 항목 과는 다른 경향을 나타내었다.

도로형태에 따른 분석 항목별 첨두수질농도의 경우 고속 
도로의 경우 SS 항목이 중간값(madian) 기준으로 강우사상 에 따른 농도 변동성이 가장 낮은 것으로 조사되었으며, 기타 항목의 경우 강우사상에 따른 변동성이 큰 것으로 조사되었다. 국도의 경우 $\mathrm{COD}$ 항목의 농도 변동성이 가장 낮은 것으로 조사되었으며, 간선도로의 경우 고속도로와 동일하게 SS 항목이 강우사상에 따른 변동성이 가장 낮게 조사되었다. 첨두수질농도 도달시간은 전 항목 기준으로 평균값을 살펴보면, 고속도로 1.67 시간, 국도 0.95 시간, 간선 도로 0.99 시간으로 강우 시작 후 다소 빠른 시간 내에 첨두수 질을 나타내는 것으로 조사되었다. 첨두수질농도 도달까지 의 누적강수량은 전 항목 기준 평균값은, 고속도로 $5.1 \mathrm{~mm}$, 국도 $2.7 \mathrm{~mm}$ 및 간선도로 $2.0 \mathrm{~mm}$ 로 강우 시작 후 누적강수량이 $10 \mathrm{~mm}$ 가 되기 전에 첨두수질농도를 나타내는 것으로 조사되 어 이를 통해 불투수율이 높은 도로의 경우, 초기우수관리의
중요성을 다시 한 번 확인 할 수 있었다. 도로형태별 첨두유량 은 평균 $0.8 \mathrm{~m}^{3} / \mathrm{sec}$ 로 조사되었으며, 첨두유량 도달 시간은 5.8 시간으로 도로 형태에 따른 차이가 작은 것으로 조사되었 다. 첨두유량 도달까지의 누적강수량은 평균 $21.6 \mathrm{~mm}$ 로 조사 되었다.

도로 형태별 비점오염원에 대한 유량가중평균농도(EMCs, Event Mean Concentrations)를 산정하여 Table 5 및 Fig. 3 에 나타내었다.

각각의 강우사상에 대한 $\mathrm{EMCs}$ 를 산정한 후 강우계급별 구분하여 제시하였으며, 강우계급의 구분 기준은 국립환경 과학원 강우유출수조사방법에 준하였다. 비점오염원 유량 가중평균농도의 경우 강우사상에 따른 값의 변화가 다양하 고, 동일한 지역에 동일한 강우사상이더라도 유출수의 양과 수질 변화가 큰 특성을 나타낸다. 이러한 비점오염원 농도

Table 5. EMCs Calculation of Nonpoint Sources Pollution by Rainfall

(Unit: $\mathrm{mg} / \mathrm{L}$ )

\begin{tabular}{|c|c|c|c|c|c|c|}
\hline Sites & $\begin{array}{l}\text { Precipitation class } \\
(\mathrm{mm})\end{array}$ & BOD & COD & SS & T-N & T-P \\
\hline \multirow{4}{*}{ Highway } & $0 \sim 10$ & 3.0 & 16.8 & 21.0 & 2.975 & 0.206 \\
\hline & $10 \sim 30$ & 6.5 & 15.7 & 23.0 & 2.308 & 0.203 \\
\hline & $30 \sim 50$ & 4.8 & 20.1 & 16.2 & 2.482 & 0.158 \\
\hline & $>50$ & 3.7 & 11.5 & 17.9 & 1.557 & 0.127 \\
\hline \multirow{4}{*}{ National road } & $0 \sim 10$ & 10.0 & 23.1 & 14.7 & 6.055 & 0.074 \\
\hline & $10 \sim 30$ & 4.8 & 10.2 & 16.9 & 2.513 & 0.101 \\
\hline & $30 \sim 50$ & 4.6 & 11.7 & 11.0 & 2.014 & 0.078 \\
\hline & $>50$ & 1.8 & 3.6 & 12.3 & 2.440 & 0.067 \\
\hline \multirow{4}{*}{ Trunk road } & $0 \sim 10$ & 21.1 & 108.8 & 3.3 & 77.0 & 2.055 \\
\hline & $10 \sim 30$ & 10.9 & 39.0 & 3.2 & 34.2 & 0.983 \\
\hline & $30 \sim 50$ & 19.7 & 66.6 & 2.4 & 70.1 & 0.514 \\
\hline & $>50$ & 3.3 & 8.2 & 0.6 & 20.3 & 0.368 \\
\hline
\end{tabular}

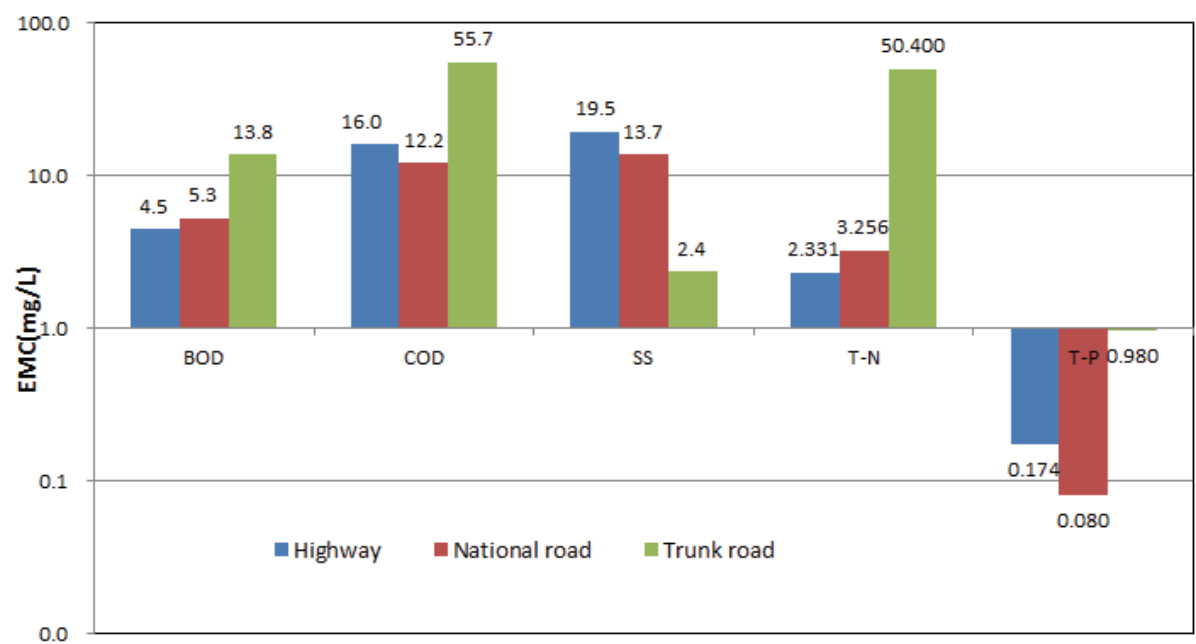

Fig. 3. Average EMCs by Road Type 
특성에 따라 EMCs를 강우계급별로 구분하고 제시하였다. 도로 형태에 따른 $\mathrm{EMCs}$ 의 경우 평균값으로 살펴보면 고속 도로의 경우 BOD $4.5 \mathrm{mg} / \mathrm{L}, \mathrm{COD} 16.0 \mathrm{mg} / \mathrm{L}$, SS $19.5 \mathrm{mg} / \mathrm{L}$, T-N $2.331 \mathrm{mg} / \mathrm{L}$, T-P $0.174 \mathrm{mg} / \mathrm{L}$ 로 조사되었다. 국도의 경우 BOD $5.3 \mathrm{mg} / \mathrm{L}$, COD $12.2 \mathrm{mg} / \mathrm{L}$, SS $13.7 \mathrm{mg} / \mathrm{L}$, T-N 3.256 $\mathrm{mg} / \mathrm{L}, \mathrm{T}-\mathrm{P} 0.080 \mathrm{mg} / \mathrm{L}$ 로 조사되었으며, 간선도로의 경우 BOD $13.8 \mathrm{mg} / \mathrm{L}$, COD $55.7 \mathrm{mg} / \mathrm{L}$, SS $2.4 \mathrm{mg} / \mathrm{L}$, T-N 50.400 $\mathrm{mg} / \mathrm{L}$, T-P $0.980 \mathrm{mg} / \mathrm{L}$ 로 조사되었다. 간선도로의 경우 다른 도로에 비해 $\mathrm{SS}$ 를 제외한 전 항목의 농도가 높게 조사되었다. 조사대상 간선도로의 경우, 타 도로에 비해 차량 통행량이 많고, 이륜차 및 도보로도 활용되는 특징을 가지고 있다. 이러한 도로 특징으로 인한 음식물 혼합 쓰레기 투기 및 도로 주변 화단에 대한 퇴비 적재, 살포가 원인으로 적용된 것으로 판단된다.

2007년부터 2013년까지 낙동강수계에 분포된 도로(교통 지역)형태별 강우 유출수를 분석하여 비점오염원 원단위를 산정하였다. 비점오염원원단위는 현재 수질오염총량제 시 행을 위해 특정유역에 대한 토지계 배출부하량을 산정하기 위해 적용하고 있으며, 현재까지 대분류 토지피복체계에
대한 원단위만 적용되고 있는 실정이다. 향후 토지계 비점오 염원 원단위 개정을 통해 새로이 산정된 원단위가 적용될 예정이며, 본 연구에서는 대상유역 모니터링 결과를 활용하 여, 교통지역 원단위를 산정하고, 기존 수질오염총량지침에 서 적용되고 있는 원단위와 비교 후 이를 활용하여 도로에 적용될 수 있는 비점저감시설의 삭감부하량을 산정하고자 하였다.

중분류 토지피복 기준 교통지역에 대해 산정된 비점오염 원 원다위는 BOD $12.42 \mathrm{~kg} / \mathrm{km}^{2} / \mathrm{day}, \mathrm{T}-\mathrm{N} 7.553 \mathrm{~kg} / \mathrm{km} / \mathrm{day}$, T-P $0.391 \mathrm{~kg} / \mathrm{km}^{2} / \mathrm{day}$ 로 산정되었다(Table 6). 기존 수질오염 총량관리지침 기준 토지계 비점원단위의 경우 BOD 17.76 $\mathrm{kg} / \mathrm{km} / \mathrm{day}$, T-N $13.69 \mathrm{~kg} / \mathrm{km}^{2} / \mathrm{day}$, T-P $0.631 \mathrm{~kg} / \mathrm{km}^{2} / \mathrm{day}$ 로 본 연구에서 산정된 원단위에 비해 다소 높게 적용되었다. 기존 활용되고 있던 원단위의 경우 대분류 기준으로 제시되어 있으며, 해당 대분류군 내에는 주거, 상업, 공업 등 다양한 불투수지역의 원단위를 종합하여 대푯값을 제시하고 있었 다. 하지만 본 연구에서 산정된 원단위는 교통지역(도로)에 서의 강우 시 유출수 기준으로 산정하여 기존 대분류 값에 비해 작게 산정된 것으로 판단된다.

Table 6. Loads Per Unit Area of Nonpoint Pollution Source for Traffic Area

(unit: $\mathrm{kg} / \mathrm{km}^{2} /$ day)

\begin{tabular}{|c|c|c|c|}
\hline Land cover type & BOD & $\mathrm{T}-\mathrm{N}$ & $\mathrm{T}-\mathrm{P}$ \\
\hline Level-2 land cover ${ }^{1)}$ & 12.42 & 7.553 & 0.391 \\
\hline Land category in TMDLs $^{2)}$ & 17.76 & 13.69 & 0.631 \\
\hline
\end{tabular}

1) NIER (2014), 'Results and Application of Nonpoint Source Pollution', NPS unit revision(plan) public hearing presentation materials

2) NIER (2014), Guideline for total maximum daily loads of water quality management

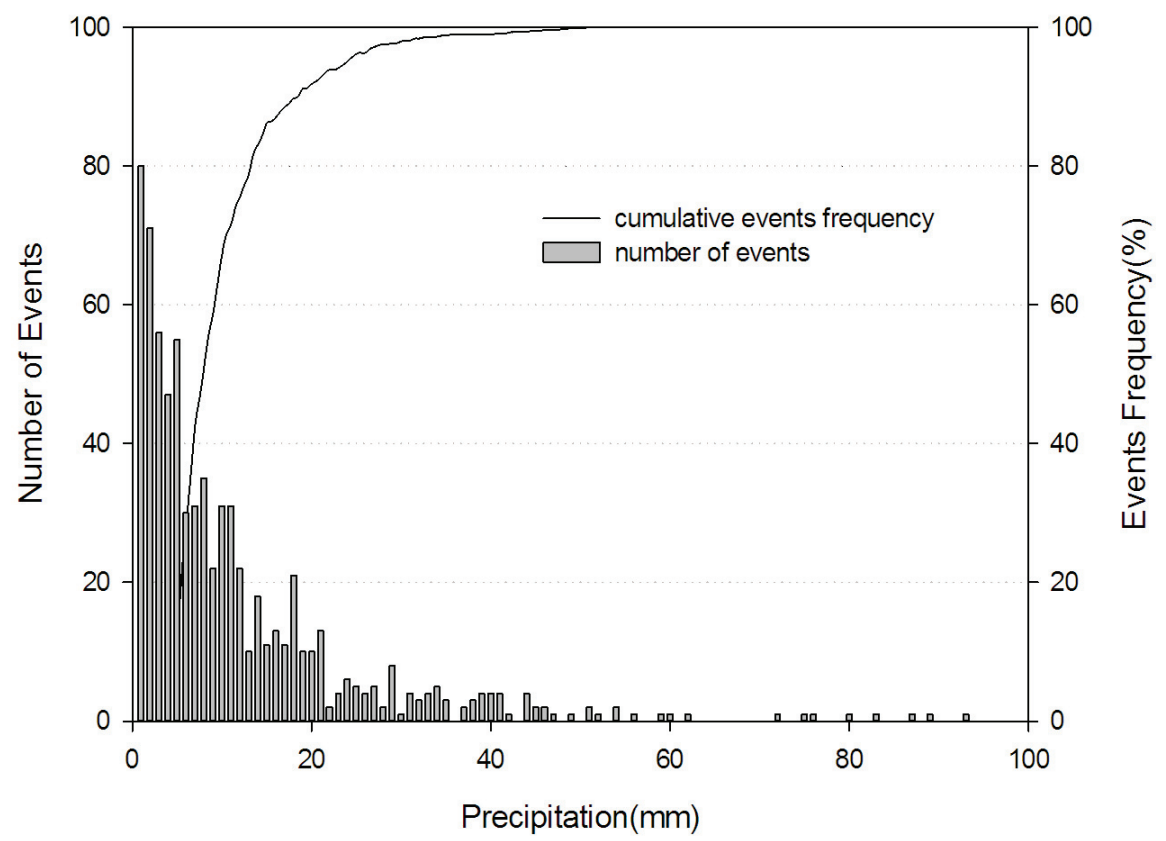

Fig. 4. Precipitation Frequency Histogram (Jinju, Changwon, 2008 2017) 
조사대상지점에 대한 설계강우량 $(\mathrm{P}, \mathrm{mm})$ 산정을 위해 대상지역 기상청의 10 년간 발생 강우사상 중 $5 \mathrm{~mm}$ 이상의 사상을 Histogram을 작성하였다(Fig. 4). 본 연구에서는 설계 용량 기준을 누적발생빈도확률 기준 $90 \%$ 에 해당하는 강우 량을 기준으로 하였으며, 이에 따라 대상지역 설계강우량이 $18.5 \mathrm{~mm}$ 로 산정되었다.

낙동강수계 교통지역에 대한 비점오염원 원단위를 장기모 니터링 자료를 활용하여 산정하였으며(Table 6), 그 결과를 활용하여, 해당 도로별 저감시설별 삭감부하량을 산정하였 다(Table 7, Fig. 5). 기존 대분류 원단위 적용에 비해 중분류
토지피복 원단위 적용 시 시설별 저감효율은 침투도랑 $69.9 \%$, 수목여과박스 $55.2 \%$, 침투측구 $62.0 \%$ 감소하는 것으로 조사 되었다. 중분류 원단위 기준 산정된 삭감부하량은 대상 유역 에서 도로개발 시 사전 적용 후 해당 개발에 따른 부하량을 평가 할 수 있는 근거 자료가 된다. 기존 대분류 토지계 비점원단위의 경우 불투수 토지피복(주거, 공업, 상업, 교통 등)에 대해 공통적인 원단위 값을 적용하여, 분석하고자 하는 특정 피복에 대한 정확한 부하량 산정은 어려운 실정이 었다. 본 연구에서는 교통지역에 대해 산정된 원단위를 적용 하여 부하를 산정하였으며, 이러한 원인으로 인해 원단위

Table 7. Estimation of Reduction Facility Reduction Load by Application of Unit Change

\begin{tabular}{|c|c|c|c|c|c|c|c|}
\hline \multirow[b]{2}{*}{ Road type } & \multirow[b]{2}{*}{ NPS } & \multicolumn{2}{|c|}{ Infiltration box } & \multicolumn{2}{|c|}{ Trees filtration box } & \multicolumn{2}{|c|}{ Infiltration gutter } \\
\hline & & $\begin{array}{c}\text { Level-2 land } \\
\text { cover }\end{array}$ & $\begin{array}{c}\text { Land category in } \\
\text { TMDLs }\end{array}$ & $\begin{array}{c}\text { Level-2 land } \\
\text { cover }\end{array}$ & $\begin{array}{c}\text { Land category in } \\
\text { TMDLs }\end{array}$ & $\begin{array}{l}\text { Level-2 land } \\
\text { cover }\end{array}$ & $\begin{array}{c}\text { Land category in } \\
\text { TMDLs }\end{array}$ \\
\hline \multirow{3}{*}{ Highway } & BOD & 0.0126 & 0.0180 & 0.0088 & 0.0126 & 0.0086 & 0.0124 \\
\hline & $\mathrm{T}-\mathrm{N}$ & 0.0062 & 0.0111 & 0.0049 & 0.0088 & 0.0071 & 0.0129 \\
\hline & $\mathrm{T}-\mathrm{P}$ & 0.0004 & 0.0006 & 0.0003 & 0.0005 & 0.0002 & 0.0004 \\
\hline \multirow{3}{*}{ National Road } & BOD & 0.0779 & 0.1114 & 0.0546 & 0.0781 & 0.0536 & 0.0767 \\
\hline & $\mathrm{T}-\mathrm{N}$ & 0.0381 & 0.0691 & 0.0301 & 0.0546 & 0.0443 & 0.0803 \\
\hline & $\mathrm{T}-\mathrm{P}$ & 0.0023 & 0.0038 & 0.0021 & 0.0033 & 0.0015 & 0.0024 \\
\hline \multirow{3}{*}{ Trunk Road } & BOD & 0.0193 & 0.0277 & 0.0136 & 0.0194 & 0.0133 & 0.0190 \\
\hline & $\mathrm{T}-\mathrm{N}$ & 0.0095 & 0.0172 & 0.0075 & 0.0136 & 0.0110 & 0.0199 \\
\hline & $\mathrm{T}-\mathrm{P}$ & 0.0006 & 0.0009 & 0.0005 & 0.0008 & 0.0004 & 0.0006 \\
\hline
\end{tabular}

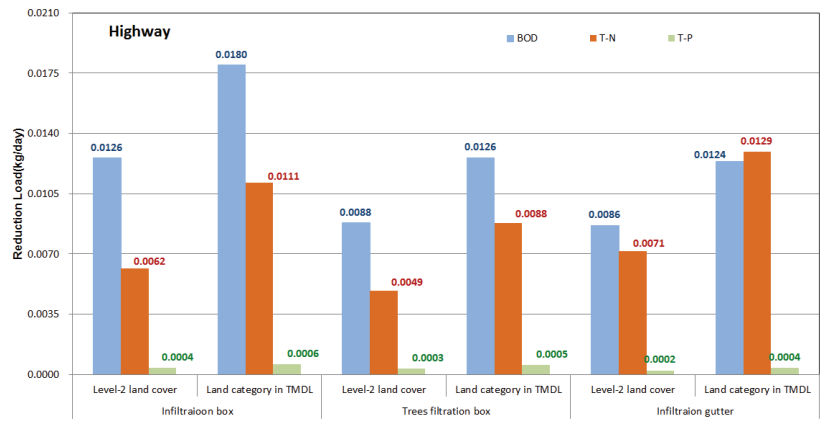

(a) Highway

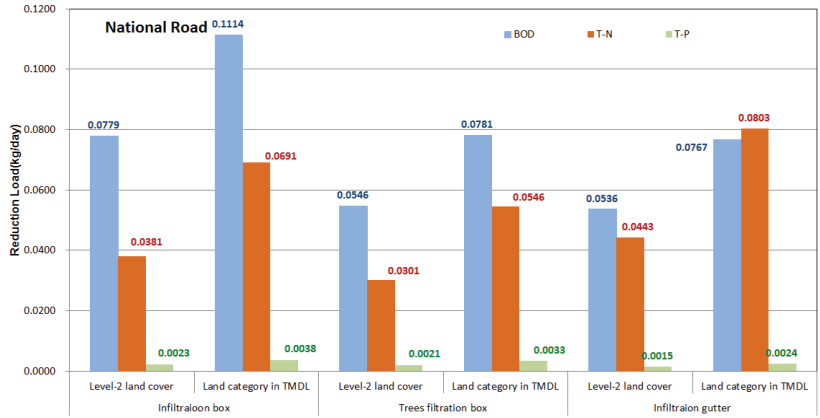

(b) National road

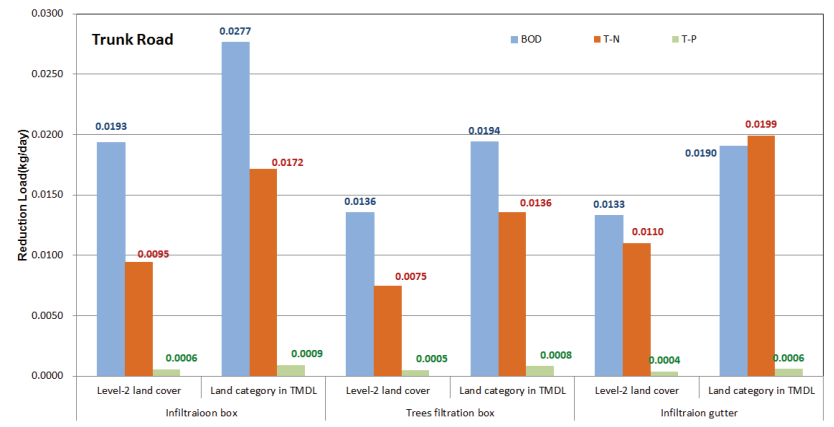

(c) Trunk road

Fig. 5. Estimation of Reduction Load by Facility According to Change of Load Per Unit Area 
감소에 따른 저감효율 감소 결과를 나타낸 것으로 사료된다. 대상 도로에 적용된 저감시설별 삭감부하량을 비교해 본 결과, $\mathrm{BOD}$ 의 경우, 침투도랑의 삭감부하량이 가장 큰 것으 로 조사되었으며, 수목여과박스와 침투측구의 삭감부하량 은 유사하게 산정되었다(고속도로: 수목여과박스 0.0088 $\mathrm{kg} / \mathrm{day}$, 침투측구 $0.0086 \mathrm{~kg} / \mathrm{day}$, 국도: 수목여과박스 0.0546 $\mathrm{kg} / \mathrm{day}$, 침투측구 $0.0538 \mathrm{~kg} / \mathrm{day}$, 간선도로: 수목여과박스 $0.0136 \mathrm{~kg} / \mathrm{day}$, 침투측구 $0.033 \mathrm{~kg} / \mathrm{day}) . \mathrm{T}-\mathrm{N}$ 의 경우 침투측구 의 저감효율이 가장 큰 것으로 조사되었으며, 다음으로 침투 도랑 > 수목여과박스 순으로 저감효율 차이를 나타내었다. T-P의 경우 저감시설에 따른 저감효율 차이는 크게 나타나지 않는 것으로 분석되었다. 저감시설에 대한 저감효율을 평가 해 본 결과 항목별로는 $\mathrm{BOD}>\mathrm{T}-\mathrm{N}>\mathrm{T}-\mathrm{P}$ 순으로 삭감부하량 차이를 나타내었다.

\section{4. 결 론}

본 연구에서는 낙동강수계 교통지역에서의 장기모니터링 결과를 활용하여, 대상 피복에 대한 유출특성을 분석하고, 비점오염원 원단위를 산정하였다. 산정된 원단위 및 기존 수질 오염총량지침에서 적용되고 있는 대분류 원단위를 활용하여 대상유역인 교통지역에 대한 비점오염원 저감시설별 삭감부 하량을 산정하여 비교하였으며, 그 결과는 아래와 같다.

(1) 낙동강수계 교통지역에 대한 장기모니터링 자료 분석 결과, 선행무강우일수는 평균 6.7 일로 조사되었으며, 해당 지점의 강우량은 평균 $31.3 \mathrm{~mm}$, 강우지속시간은 9.1시간으로 조사되었다. 조사대상 지점은 도로의 경 우 형태에 따른 일부 조경에 의한 차이는 있으나 $100 \%$ 불투수율을 나타내는 토지피복으로 적은 강우량에도 유출을 나타내는 특성을 보였다.

(2) 첨두수질농도 도달시간은 전 항목 기준으로 평균, 고속 도로 1.67 시간, 국도 0.95 시간, 간선도로 0.99 시간으로 강우 시작 후 다소 빠른 시간 내에 첨두수질을 나타내는 것으로 조사되었다. 첨두수질농도 도달까지의 누적강 수량은 전 항목 기준 평균값은, 고속도로 $5.1 \mathrm{~mm}$, 국도 $2.7 \mathrm{~mm}$ 및 간선도로 $2.0 \mathrm{~mm}$ 로 강우 시작 후 누적강수량이 $10 \mathrm{~mm}$ 가 되기 전에 첨두수질농도를 나타내는 것으로 조사되어 이를 통해 불투수율이 높은 도로의 경우, 초기우수관리의 중요성을 다시 한 번 확인 할 수 있었다. 도로형태별 첨두유량은 평균 $0.8 \mathrm{~m}^{3} / \mathrm{sec}$ 로 조사되었으 며, 첨두유량 도달 시간은 5.8시간으로 도로 형태에 따른 차이가 작은 것으로 조사되었다. 첨두유량 도달까 지의 누적강수량은 평균 $21.6 \mathrm{~mm}$ 로 조사되었다.

(3) 도로 형태별 비점오염원에 대한 유량가중평균농도 $(\mathrm{EMCs})$ 의 경우 각각의 강우사상에 대한 $\mathrm{EMCs}$ 를 산 정한 후 강우계급별 구분하여 제시하였다. 비점오염
원 유량가중평균농도의 경우 강우사상에 따른 값의 변화가 다양하고, 동일한 지역에 동일한 강우사상이 더라도 유출수의 양과 수질 변화가 큰 특성을 나타낸 다. 이러한 비점오염원 농도 특성에 따라 $\mathrm{EMCs}$ 를 강우계급별로 구분하고 제시하였다.

(4) 중분류 토지피복 기준 교통지역에 대해 비점오염원 원단위를 산정한 결과, BOD $12.42 \mathrm{~kg} / \mathrm{km} / \mathrm{day}, \mathrm{T}-\mathrm{N}$ $7.553 \mathrm{~kg} / \mathrm{km} / \mathrm{day}$, T-P $0.391 \mathrm{~kg} / \mathrm{km} / \mathrm{day}$ 로 산정되었다. 기존 수질오염총량관리지침 기준 토지계 비점원단위 의 경우 BOD $17.76 \mathrm{~kg} / \mathrm{km}^{2} / \mathrm{day}$, T-N $13.69 \mathrm{~kg} / \mathrm{km}^{2} / \mathrm{day}$, T-P $0.631 \mathrm{~kg} / \mathrm{km}^{2} / \mathrm{day}$ 로 본 연구에서 산정된 원단위에 비해 다소 높게 적용되었다. 기존 활용되고 있던 원단 위의 경우 대분류 기준으로 제시되어 있으며, 해당 대분류군 내에는 주거, 상업, 공업 등 다양한 불투수지 역의 원단위를 종합하여 대푯값을 제시하고 있었다. 하지만 본 연구에서 산정된 원단위는 교통지역(도로) 에서의 강우 시 유출수 기준으로 산정하여 기존 대분 류 값에 비해 낮게 산정된 것으로 판단된다.

(5) 중분류 원단위 기준 산정된 삭감부하량은 대상 유역에 서 도로개발 시 사전 적용 후 해당 개발에 따른 부하량 을 평가 할 수 있는 근거 자료가 된다. 기존 대분류 토지계 비점원단위의 경우 불투수 토지피복(주거, 공 업, 상업, 교통 등)에 대해 공통적인 원단위 값을 적용하 여, 분석하고자 하는 특정 피복에 대한 정확한 부하량 산정은 어려운 실정이었다. 본 연구에서는 교통지역에 대해 산정된 원단위를 적용하여 부하를 산정하였으며, 이러한 원인으로 인해 원단위 감소에 따른 저감효율 감소 결과를 나타낸 것으로 사료된다.

(6) 교통지역과 같은 불투수율이 높은 유역에서의 강우유 출수는 하천에 직접적으로 유입되어 수질오염을 일으 키는 주요 오염원으로 인식되고 있다. 현재 환경부에 서 시행되고 있는 '물순환선도도시' 사업과 같이 강우 및 우출수 관리를 통해 물순환을 원활히 하여 수질오염 저감, 지하수 및 유지용수 확보 등과 같은 다양한 효과 를 기대하고 있다. 본 연구와 같은 기초조사를 통하여 특정 토지피복에서의 비점오염원 유출 특성을 규명하 고, 대상 피복에 적용 할 수 있는 비점원단위 및 삭감부 하량을 산정하였다. 향후 장기적인 모니터링을 통해 토지피복 변화에 대응 할 수 있는 개정 비점원단위가 추가 산정 되어야 할 것으로 판단되며, 더불어 토지피 복 체계 또한 세분류로 구분할 수 있는 연구가 추가 되어야 할 것으로 사료된다.

\section{감사의 글}

“이 논문은 2017년도 경남과학기술대학교 기성회 연구비 지원에 의하여 연구되었음." 


\section{References}

Choi, J.Y., and Shin, E.S. (1997) Study on Management Method of Nonpoint Source Pollution in Urban Area. Korea Environment Institute.

Committee for the Nakdong River Water Management System (2007) A Monitoring and Management Scheme for the Non-Point Sources.

Committee for the Youngsan River - Seomjin River Water Management System (2015) Water Recycle Study by Using Rainwater Infiltration, Storage, Reuse and etc., (Forcus on Gwangju Urban Area).

Hong, J., and Kim, L. (2016) Assessment of Performances of Low Impact Development Facilities with Vegetation. Ecology and Resilient Infrastructure, Vol. 3, No. 2, pp. 100-109.

Kwon, H.G. (2011) Quantitative Assessment of Nonpoint Source Load by Applying Watershed Model and Level-2 Land Cover Map. Ph.D. dissertation, Kyungpook National University, Daegu, Korea.

Kwon, S.K. (1998) Management Improvement and Perspective on Nonpoint Sources of Water Pollution in Korea. Journal of Korean Society of Environmental Engineers, Vol. 20, No. 11, pp. 1497-1510.

Lee, D. (2016) Restoration of water Cycle by a Rainwater Management System Applied to LID. Ecology and Resilient Infrastructure, Vol. 3, No. 2, pp. 130-133.

MOE (Ministry of Environment) (1995) Nonpoint Source Pollution Research Project Report.

MOE (Ministry of Environment) (2016) Manual for Installation and Management of Nonpoint Pollution Reduction Facilities.
Moore, T. and Hunt, W. (2012) Ecosystem Service Provision by Stormwater Wetland and Ponds - A Mean for Evaluation. Water Research, Vol. 46, pp. 6811-6823.

NIER (National Institute of Environmental Research) (2012) Rainfall Runoff Investigation Method.

NIER (National Institute of Environmental Research) (2013) Study on the Design Criteria Rainfall and Flowrate for Structural BMPs.

NIER (National Institute of Environmental Research) (2014) Results and Application of Nonpoint Source Pollution. NPS Unit Revision(Plan) Public Hearing Presentation Materials.

NIER (National Institute of Environmental Research) (2014) Technical Guidelines for TMDLs. 11-1480523-001 067-01.

Shin, C.M., Choi, J.Y., and Park, C.H. (2004) Characteristics of Non-point Pollution Discharge with Land Use in Urban Area. Journal of Korean Society of Environmental Engineers, Vol. 26, No. 7, pp. 729-735.

Shin, D.S. (2007) Basic Monitoring Concept for Revised Unit-Load on NPS. J. of Korean Society on Water Quality, Vol. 23, No. 4, pp. 429-433.

Valinski, N. and Chandler, D. (2015) Infiltration Performance of Engineered Surface Commonly Used for Distributed Stormwater Management. J. of Environmental Management, Vol. 160, pp. 297-305.

\begin{tabular}{|l|l|}
\hline Received & January 25, 2018 \\
\hline Revised & January 29, 2018 \\
\hline Accepted & February 13, 2018 \\
\hline
\end{tabular}

